\title{
THE CONCEPT OF INSTITUTIONAL ARBITRATION - NEED FOR THE HOUR
}

\author{
Dr. Sachin Rastogi ${ }^{1}$, Ms. Charu Shahi ${ }^{2}$
}

\begin{abstract}
The Indian lawmakers have an agenda to promote India as an Arbitration hub for solving disputes, thus, they brought about certain changes to the Arbitration and Conciliation Act, 1996 by way of an amendment namely, the Arbitration and Conciliation (Amendment) Act, 2015 ("2015 Amendments") which aimed at achieving this goal by facilitating speedy and efficacious resolution of disputes through arbitration. It is widely accepted that India prefers ad hoc arbitration over institutional arbitration. Though various arbitral institutions have been set up in India, especially in the last five years, ad hoc arbitration continues to be the preferred mode of arbitration. Moreover, a large number of international arbitrations involving Indian parties are seated abroad and administered by foreign arbitral institutions. In order to promote institutional arbitration in India, it is imperative that: (a) Indian parties involved in domestic and international arbitrations are encouraged to shift to institutionally administered arbitrations rather than resort to ad hoc arbitrations; and (b) India becomes a favored seat of arbitration for international arbitrations, at the very least in matters involving Indian parties. With this background, this paper delineates certain issues that exist in the Institutional Arbitration in India and identifies areas for reform in the Indian arbitration, to strengthen the existing arbitration mechanisms, and also to put forward focus areas for promoting institutional arbitration in India.
\end{abstract}

\section{INTRODUCTION}

Arbitration may be defined as "the process by which a dispute or difference between two or more parties as to their mutual legal rights and liabilities is referred to and determined judicially with binding effect by the application of law by one or more persons instead of a court of law". ${ }^{1}$ The objective of arbitration is to provide fair and impartial resolution of disputes at a fast rate by minimizing the expense and at the same time, it allows freedom to the parties to agree upon the manner in which their disputes should be resolved, subject only to safeguards imposed in public interest.

In India, Arbitration as a mode of resolution of disputes came to be adopted from the medieval times when trade and commerce between traders in India and outside started growing. ${ }^{2}$ Prior to 1996, in India, laws governing arbitration were encompassed in three enactments; The Arbitration Act, 1940 contained general provisions pertaining to arbitration; The Arbitration (Protocol and Convention) Act, 1937 and The Foreign Awards (Recognition and Enforcement) Act, 1961 dealt with the enforcement of foreign arbitration awards. This factor and the interpretational interplay between three different

${ }^{1}$ Butterworths, HALSBURY'S LAW OF ENGLAND (4th edition, 1991) 601 enactments ensured that simplicity, speed and efficiency, were never going to be there.

Post 1996, following much persuasion from the various bodies of trade, the Arbitration \& Conciliation Act, 1996 was promulgated. Commendably, the Act was based on the United Nations Commission on International Trade Law (UNCITRAL) Model Law, which was recommended by the General Assembly of the United Nations to all countries. The influence of the UNCITRAL Model Law ensured some uniformity of the Act with arbitration worldwide, which was not entirely unwelcome as the Indian economy was undergoing a sea-change following the crisis of 1991.

Today, Arbitration is a very popular mode of alternate dispute resolution in the commercial world and one can find an arbitration clause incorporated in the majority of business contracts.Parties are entitled to choose the form of arbitration, which they deem appropriate in the facts and circumstances of their dispute. This necessarily involves the consideration and evaluation of the various features of both forms of arbitration and this can be a daunting task, as both forms have their own merits and demerits.

${ }^{2}$ Alternate Dispute Resolution, 13 (P.C. Rao\& William Sheffield eds., Universal Law Publishing co. Pvt. Ltd.). 


\section{TYPES OF ARBITRATION 3}

Arbitration, as mentioned above, can be divided into two basic forms, Ad-Hoc Arbitration and Institutional Arbitration.

\section{AD-HOC ARBITRATION}

Ad-hoc arbitration refers to 'arbitration where the parties and the arbitral tribunal will conduct the arbitration according to procedures which will either be agreed by the parties or, in default of agreement, laid down by the arbitral tribunal at the preliminary meeting once the arbitration has begun. However, there are different sets of rules available to parties who contemplate arbitration, including the rules of their own trade associations. ${ }^{4}$
A peculiarity that came about was that in an arbitration consisting of three arbitrators, each party would appoint one arbitrator and the two arbitrators would jointly appoint the presiding arbitrator. By custom, the two arbitrators would only appoint a presiding arbitrator who was senior to both and prefer to appoint retired Chief Justices of India. Parties mostly prefer to appoint retired judges of the High Court or the Supreme Court, depending on, amongst other things, the quantum of the claim. Nowadays, given the huge demand for such limited senior judges, parties are often faced with a scenario where the dates between hearings could even be as long as one year, thus negating the entire concept of arbitration as a quick and efficient mechanism for dispute resolution. ${ }^{5}$

\begin{tabular}{|c|c|}
\hline Merits of Ad-Hoc Arbitration ${ }^{6}$ & De-merits of Ad Hoc Arbitration \\
\hline $\begin{array}{l}\text { - } \text { Greater control over the arbitration process } \\
\text { - The flexibility to decide the procedure } \\
\text { administration charges levied by an arbitral } \\
\text { institution constitute a significant portion of the } \\
\text { overall costs }\end{array}$ & $\begin{array}{l}\text { - Tend to be protracted and costly in some } \\
\text { cases in the absence of monitoring } \\
\text { - Only effective when both parties are ready } \\
\text { to cooperate with each other }\end{array}$ \\
\hline
\end{tabular}

\section{INSTITUTIONAL ARBITRATION}

Institutional arbitration refers to 'the administration of arbitration by an institution in accordance with its rules of procedure'. The institution provides appointment of arbitrators, case management services including oversight of the arbitral process, venues for holding hearings, etc.A large number of well-known and internationally recognized institutional arbitration centers such as the International Chamber of Commerce, the London Court of International Arbitration and the Permanent Court of Arbitration have opened centers in India. Presently there are over 35 arbitral institutions in India, which are domestic, international arbitral

\footnotetext{
${ }^{3}$ Gerald Aksen, Ad hoc Verses Institutional Arbitration, 2(1) ICC Bulletin (1991): 8-14.

${ }^{4}$ Instances of such association are Grain and Feedstock Trade Association (GAFTA) and London Maritime Arbitrators Association (LMAA).

5 Krishna Sarma et al., 'Development and Practice of Arbitration in India - Has it Evolved as an Effective Legal Institution ', Working Paper 103, of the Center on Democracy, Development, and The Rule of Law Freeman Spogli Institute for International Studies (2009), available at
}

institutions, arbitration facilities by PSUs, trade and merchant associations, and city-specific chambers of commerce and industry. Many have their own rules and some follow the arbitration rules of the UNCITRAL.

In an Institutional Arbitration, the arbitration agreement designates an arbitral institution to administer the arbitration. The parties then submit their disputes to the institution that intervenes and administers the arbitral process as provided by the rules of that institution. The institution does not arbitrate the dispute. It is the arbitral panel which arbitrates the dispute. ${ }^{7}$

https://cddrl.fsi.stanford.edu/sites/default/files/No_103_Sarm a_India_Arbitration_India_509.pdf

${ }^{6}$ SundraRajoo, 'Institutional and Ad hoc Arbitrations: Advantages and Disadvantages', The Law Review (2010), available at http://sundrarajoo.com/wpcontent/uploads/2016/01/Institutional-and-Ad-hoc-

Arbitrations-Advantages-Disadvantages-by-SundraRajoo.pdf (

7 Alan Redfern and Martin Hunter, Law and Practice of International Commercial Arbitration, 47(4th ed., 2004) IIII 1 99. 
All Arbitral Institutions do not provide the same services. Some institutions of high reputation simply offer a set of rules and guidelines, and no other arbitral services; one such illustration is the London Maritime Arbitrators Association (LMAA), etc. There are other institutions, which provide rules and a roster of qualified arbitrators but are not involved in the appointment of arbitrators; an example is the Society of Maritime Arbitrators in New York.
Certain groups of institutions supervise the whole arbitration process from the notification to the defending party of the claimant's request for arbitration to, and including, the notification of the arbitral award to the parties. For instance, the International Court of Arbitration of The International Chamber of Commerce. $^{8}$

\begin{tabular}{|c|c|}
\hline Merits of Institutional Arbitration & De-Merits of Institutional Arbitration \\
\hline $\begin{array}{l}\text { - A clear set of arbitration rules } \\
\text { - Timeline for the conduct of an arbitration } \\
\text { - Support from trained staff } \\
\text { - A panel of arbitrators to choose from } \\
\text { - Supervision in the form of scrutiny of awards } \\
\text { - If the parties are not sophisticated and do not } \\
\text { have sufficient knowledge regarding arbitral } \\
\text { proceedings, institutional arbitration is } \\
\text { preferable } \\
\text { Resolve disputes efficiently and follow } \\
\text { guidelines when conducting arbitrations }\end{array}$ & $\begin{array}{l}\text { - Lack of credible arbitral institutions } \\
\text { - Misconceptions relating to institutional } \\
\text { arbitration related to costs } \\
\text { - Lack of governmental support for institutional } \\
\text { arbitration } \\
\text { - Lack of legislative support for institutional } \\
\text { arbitration } \\
\text { - Judicial attitudes towards arbitration in } \\
\text { general. } \\
\text { - The rules and practices followed are often } \\
\text { outdated and inadequate } \\
\text { - Fails to upgrade their administrative and } \\
\text { working style as only provide hearing venues } \\
\text { with basic facilities and lack more advanced } \\
\text { facilities such as multi-screen video } \\
\text { conferencing, sound-proof caucus rooms, } \\
\text { audio/video recording, court recorders, etc. } \\
\text { - Inflexible as it takes away the exclusive } \\
\text { autonomy of the parties over arbitration } \\
\text { proceedings } \\
\text { Delays in Indian courts and excessive judicial } \\
\text { involvement in arbitral proceedings } \\
\text { contributed to discouraging foreign parties to } \\
\text { arbitrate in India. } \\
\text { Parties often delay arbitration proceedings by } \\
\text { initiating court proceedings before or during } \\
\text { arbitral proceedings, or at the enforcement } \\
\text { stage of the arbitral award. }\end{array}$ \\
\hline
\end{tabular}

\section{CHALLENGES FACED BY INSTITUTIONAL ARBITRATION IN INDIA}

\footnotetext{
${ }^{8}$ G.K. Kwatra, Arbitration and Alternative Dispute Resolution, 59 (Universal Law publishing co., 2008).
}

It is widely accepted that India prefers $\mathrm{Ad} \mathrm{Hoc}$ Arbitration over Institutional Arbitration. Though various arbitral institutions have been set up in India, especially in the last five years, ad hoc arbitration 
continues to be the preferred mode of arbitration. Moreover, a large number of international arbitrations involving Indian parties are seated abroad and administered by foreign arbitral institutions. ${ }^{9}$ Challenges to Institutional Arbitration in India, examines the reasons why Institutional Arbitration is not the preferred mode of arbitration in India, with particular focus on: (1) misconceptions regarding institutional arbitration;

(2) lack of governmental support for institutional arbitration;

(3) lack of statutory backing for institutional arbitration; and

(4) problems with delays and excessive judicial involvement in arbitration proceedings.

\section{Misconceptions Regarding Institutional}

Arbitration- There are several misconceptions relating to institutional arbitration that exist among parties. One of these is related to costs. Parties consider Institutional Arbitration to be substantially more expensive than ad Hoc Arbitration, primarily because of the administrative fees payable to arbitral institutions. ${ }^{10}$

This assessment is largely misconceived because:

(a) numerous arbitral institutions charge very reasonable fees;

(b) the use of an arbitral institution helps avoid disputes over procedural matters resulting in cost savings; and

(c) the costs of an ad hoc arbitration can easily exceed the costs of an institutional arbitration in case of additional procedural hearings, adjournments, use of per-hearing fees, litigation arising from procedural infirmities in ad hoc arbitrations etc.

Parties also often believe that institutional arbitration is inflexible because arbitral institutions follow rules that take away exclusive autonomy of the parties over arbitration proceedings. However, most arbitral institutions that exist in the international scenario have made an attempt to balance institutionalisation with

\footnotetext{
${ }^{9}$ Statistics show that 91 of the 271 cases administered by the Singapore International Arbitration Centre (SIAC) last year involved Indian parties, which amounts to twice as many as the Chinese users, who filed the second-highest number of cases. See Sathyapalan and Sivaraman, 'A Lot Still Needs to Be Done For India to Fulfil Its International Arbitration Ambitions', The Wire (Online) on 02.11.2016, available at https://thewire.in/77002/international-arbitration-india/ (accessed on 26.02.2017)
}

party autonomy;they only keep those issues which deal with the legality and integrity of proceedings out of the purview of party autonomy.

These misconceptions could be due to a general lack of awareness regarding institutional arbitration and its advantages. This could also be due to the lack of initiative on the part of arbitral institutions to promote their work and facilities as well as on the part of lawyers to properly advise parties about the advantages of institutional arbitration. Even when there is awareness on the existence of institutional arbitration as an option, there is often the misconception that this option is only available to bigger businesses and/or high value disputes.

\section{Governmental Support For Institutional} Arbitration- One of the reasons for a weak Institutional Arbitration framework in India is the lack of sufficient governmental support for the same over the years. While the government is the most prolific litigant in India, it can do more in this capacity to encourage institutional arbitration. The general conditions of contract used by the government and public sector undertakings often contain arbitration clauses, but these clauses usually do not expressly provide for institutional arbitration.

Further, the government policy on arbitration requires a relook if institutional arbitration is to become the norm, particularly for disputes valued at large amounts. For instance, if the government, being the biggest litigant, were to adopt institutional arbitration as regular practice, the sheer volume of cases moving to arbitral institutions would provide a powerful impetus to Institutional Arbitration.

There have recently been discussions and initiatives on the part of some state governments as well to promote Institutional Arbitration, citing that it would be more

10 See Gary Born, 'International Arbitration: Law and Practice', 2012 Ed. p. 13. See also 'The pros and cons of arbitration', A Lexis PSL document produced in partnership with Mayer Brown International LLP, available at https://m.mayerbrown.com/Files/News/04165fd5-5165-41eabb6f19d9235c171d/Presentation/NewsAttachment/7e531e5e4040-4251-b1a8-

1d4b6168c99b/Practice\%20Note_Duncan_Pros-ConsArbitration_oct12.pdf (accessed on 02.03.2017) 
organised and cost-effective. ${ }^{11}$ One of the recommendations made by the Law Commission of India $^{12}$ was that trade and commerce bodies must establish chambers with their own rules. However, effectively, the government has so far focussed its attention on arbitration in general. To encourage Institutional Arbitration, special action aimed at the development of arbitral institutions is required.

\section{Lack Of Statutory Backing For Institutional}

Arbitration- The Act has been arbitration-agnostic, with no provisions specifically geared towards promoting institutional arbitration. This is in contrast with jurisdictions like Singapore, where the Singapore International Arbitration Centre ("SIAC") is the default appointing authority for arbitrators under the International Arbitration Act, 1994 ("IAA") which governs international arbitrations.

In fact, one of the provisions of the Act,Section 29A which was inserted by the 2015 Amendments, is perceived to have made arbitral institutions wary of arbitrations in India. Section 29A provides for strict timelines for completion of arbitration proceedings. This has been criticised as unduly restrictive of arbitral institutions which provide for timelines for different stages of the arbitration proceedings. ${ }^{13}$ The merits of such a view require examination in light of the endemic problem of delays plaguing arbitration in India.

\section{Problems With Delays And Excessive Judicial} Involvement In Arbitration- Delays in Indian courts and excessive judicial involvement in arbitration proceedings have resulted in India not being favoured as a seat for arbitration, and consequently stunted the growth of international arbitration (including institutional arbitration) in India. Parties often delay

\footnotetext{
11 'Maharashtra readies arbitration policy', Business Standard (online), 15th October 2016, available at http://www.businessstandard.com/article/economy-policy/maharashtra-readiesarbitration-policy116101400574_1.html (accessed on 17.02.2016).

${ }^{12} 246$ th Report of the Law Commission of India (August, 2014), 'Amendments to the Arbitration and Conciliation Act 1996', available

http://lawcommissionofindia.nic.in/reports/Report246.pdf (accessed on 02.03.2017).

${ }^{13}$ Special Address by Justice A.P. Shah at the NaniPalkhivala Arbitration Centre 9th Annual International Conference on Arbitration on Current Issues in Domestic and International Arbitration, 18.02.2017.
}

arbitration proceedings by initiating court proceedings before or during arbitration proceedings, or at the enforcement stage of the arbitral award. The high pendency of litigation before Indian courts means that arbitration-related court proceedings take a long time to be disposed of. The Commercial Courts Act sought to remedy this situation by setting up commercial courts at the district level or commercial divisions in high courts having ordinary original civil jurisdiction. These commercial courts / divisions hear arbitration matters involving commercial disputes, amongst other commercial matters.

However, an examination of the recent roster of the Bombay High Court, for example, indicates that commercial division judges often hear matters other than commercial matters, such as family law matters, juvenile justice-related matters etc. ${ }^{14}$ If commercial division judges are tasked with hearing matters other than commercial matters, it would detract from the legislative intent of speedy disposal of commercial matters, including arbitration matters. Additionally, we noted that the rotation policy of these High Courts was also applicable to commercial division judges. An excessively frequent rotation might hinder the creation of specialist arbitration judges who are well-versed in arbitration law and practice. Indian courts' tendency to frequently interfere in arbitration proceedings have also contributed to India's reputation as an 'arbitrationunfriendly' jurisdiction.

It is a well-known fact that courts in India are generally interventionist when it comes to regulating arbitration proceedings, whether it is at an initial stage of arbitration proceedings (such as the appointment of arbitrators, referral of disputes to arbitration or grant of interim relief) or at the enforcement stage. ${ }^{15}$ They have, despite

${ }^{14}$ Sitting List with effect from 15 November 2016 of the Bombay High Court (Original Side), available at http://bombayhighcourt.nic.in/sittinglist/PDF/sitlistbomos201 61027181818.pdf (accessed on 02.03.2017); Sitting List with effect from 4 January 2017 of the Bombay High Court (Original Side), available at http://bombayhighcourt.nic.in/sittinglist/PDF/sitlistbomos201 61222191515.pdf (accessed on 02.03.2017)

${ }^{15}$ BibekDebroy and Suparna Jain, 'Strengthening Arbitration and its Enforcement in India - Resolve in India', Research Paper of the NitiAyog (2016), p.15, available at http://niti.gov.in/writereaddata/files/document_publication/A rbitration.pdf (accessed on 02.03.2017). See also Ghani, Moin, 'Court Assistance, Interim Measures, and Public Policy: 
good intentions and justifications, often misjudged the course to take, doing justice in the case at hand but laying down questionable precedent for the future. ${ }^{16}$ Further, inconsistent judicial precedent on several crucial issues ${ }^{17}$ has contributed to uncertainty regarding the law, with severe consequences for India's reputation as a seat of arbitration.

In addition to the above-mentioned negatives of Institutional arbitration, following are the challenges of the institutional arbitration in India. ${ }^{18}$

i. Issues relating to administration and management of arbitral institutions.

ii. Perceptions regarding arbitrators and expertise issues relating to resources and government support, lack of initial capital, poor and inadequate infrastructure, lack of properly trained administrative staff, lack of qualified arbitrators, etc.

iii. Issues in developing India as an international arbitration seat.

\section{HIGH-LEVEL COMMITTEE (HLC) TO REVIEW THE INSTITUTIONALISATION OF ARBITRATION MECHANISM IN INDIA}

To address the challenges and shortcoming of the Institutional arbitration, a High-Level Committee (HLC) to Review the Institutionalisation of Arbitration Mechanism in India under Mr Justice B N Srikrishna was constituted in 2016. The committee submitted its report on 3 August, 2017. ${ }^{19}$ In relation to institutional arbitration landscape in India the committee had put forward following views: ${ }^{20}$

i. Set up an autonomous body, styled the Arbitration Promotion Council of India (APCI), having

India's Perspective on International Commercial Arbitration', The Arbitration Brief 2, no. 1: 16-29 (2012). Available at http://digitalcommons.wcl.american.edu/cgi/viewcontent.cgi? article $=1026 \&$ context $=\mathrm{ab}$ (accessed on 03.02.2017); Promod Nair, 'Ringfencing Arbitration from Judicial Interference: Proposed Changes to the Arbitration and Conciliation Act', The Practical Lawyer (2010).

${ }^{16}$ See decisions in Bhatia International v. Bulk Trading S.A., (2002) 4 SCC 105, Venture Global Engineering v. Satyam Computer Services, (2008) 4 SCC 190.

${ }^{17}$ For instance, there are conflicting decisions by two High Courts on whether two Indian parties can have a foreign seat of arbitration. See Addhar Mercantile Private Limited v. Shree representatives from all stakeholders for grading arbitral institutions in India.

ii. The APCI may

- recognize professional institutes providing for accreditation of arbitrators.

- hold training workshops and interact with law firms and law schools to train advocates with interest in arbitration.

- create a specialist arbitration bar comprising of advocates dedicated to the field.

- A good arbitration bar could help in the speedy and efficient conduct of arbitral proceedings.

iii. Creation of a specialist Arbitration Bench to deal with such commercial disputes, in the domain of the Courts. $^{21}$

iv. Changes suggested in various provisions of the 2015 Amendments of the Arbitration and Conciliation Act with a view to making arbitration speedier and more efficacious and incorporate international best practices (immunity to arbitrators, confidentiality of arbitral proceedings, etc.).

v. The Committee is also of the opinion that the National Litigation Policy (NLP) must promote arbitration in government contracts.

vi. Government's role - The Central Government and various state governments may stipulate in arbitration clauses/agreements in government contracts that only arbitrators accredited by any such recognised professional institute may be appointed as arbitrators under such arbitration clauses/agreements.

JagdambaAgrico Exports Pvt Ltd., Arbitration Application No. 197 of 2014 and Arbitration Petition No. 910 of 2013 (Bombay High Court) and Sasan Power Limited v. North American Coal Corporation India Pvt. Ltd., First Appeal No. 310 of 2015 (Madhya Pradesh High Court).

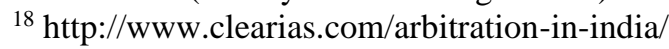

${ }^{19} \mathrm{http}: / /$ pib.nic.in/newsite/PrintRelease. aspx ?relid=155959

20 http://www.jagranjosh.com/current-affairs/committee-toreview-institutionalisation-of-arbitration-mechanism-inindia-constituted-1483098105-1

${ }^{21}$ https://www.indianbarassociation.org/what-india-needs-todo-to-make-institutional-arbitration-success-in-india/ 
WORKING AND PERFORMANCE OF THE INTERNATIONAL CENTRE FOR ALTERNATIVE DISPUTE RESOLUTION $(\text { ICADR })^{22}$

- International Centre for Alternative Dispute Resolution (ICADR) was established in 1995 for thepromotion and development of Alternative Dispute Resolution (ADR) facilities and techniques to facilitate early resolution of disputes and to reduce the increasing burden of arrears in Courts.

- The committee recommended declaring the ICADR as an Institution of national importanceand takeover of the institution by a statute as revamped ICADR has the potential be a globally competitive institution.

The reasons for choosing ICADR as the arbitral institution to be developed are: ${ }^{23}$

i. It was set up in 1995 (under the aegis of the Ministry of Law and Justice) with the object of promoting ADR in India.

ii. It has received substantial funding by way of grants and other benefits from the Government.

iii. It has some benefits like an excellent location (Headquarters at New Delhi and Regional Centres at Hyderabad and Bangalore), good infrastructure and facilities which make it ideal for development as an arbitral institution.

\section{BILATERAL INVESTMENT TREATY (BIT) ARBITRATIONS INVOLVING THE UNION OF INDIA ${ }^{24}$}

India presently involved in 20 , odd BIT disputes. The committee recommendations on Bilateral Investment Treaty Arbitrations are:

i. Create an Inter-Ministerial Committee (IMC) constituting officials from Ministries of finance, external affairs and law.

ii. Hire external lawyers having expertise in BIT.

iii. Designated fund to fight BIT claims.

iv. Appoint counsels having BIT expertise.

v. Boosting capacity of central and state governments to better understand the implications of their policy decisions on India's BIT obligation.

vi. Create a post of international law adviserresponsible for day-to-day management of BIT arbitration.

vii. Consider the possibility of establishing a BIT appellate mechanism and a multilateral investment court.

viii. Investor- state dispute settlement mechanism as given in article 15 of the Indian model BIT is an effective mechanism.

\section{COMPARATIVE ANALYSIS OF INDIAN ARBITRATION INSTITUTIONS AND OTHER SUCCESSFUL ARBITRATION INSTITUTIONS ACROSS THE GLOBE}

Institutional Arbitration in a nation flourishes only when its arbitral institutions fulfill the basic requirements to successfully and effectively carry out an arbitration process. These requirements include:

1. Degree of Permanency - Disputes frequently arise many years after the making of the original commercial agreement, particularly in long term contracts. It is important that the institutions named in the arbitration clause should still be in existence when the dispute arises, otherwise, the arbitration agreement may prove to be "inoperative or incapable of being performed", in the words of New York Convention, and the only recourse will be to the national court.

It is easier to have confidence if the institution or the centre that is chosen has an established track record or, if it is a recent creation, has some reasonable guarantee of permanency. The International Chamber Commerce and London Court of International Arbitration established in 1923 and 1892 respectively have a track record of successful arbitrations over the course of their prolonged existence.

\footnotetext{
${ }^{24}$ http://pib.nic.in/newsite/PrintRelease.aspx?relid=169621
}

\footnotetext{
${ }^{22}$ http://legalaffairs.gov.in/sites/default/files/Report-HLC.pdf
} 
The Indian Council Arbitration was established in 1965. At the beginning of the year 2010, 574 arbitration cases were pending with the Council at different stages of arbitration proceedings but by the end of that year, 579 arbitration cases were under process including 20 arbitration matters which have been pending in courts pursuant to litigation between the parties.Thus, though not as successful as the ICC or the LCIA, the ICA has shown reasonable guarantee of permanency.

2. Modern Rules of Arbitration - The practice of International Commercial Arbitration changes as new laws and procedures come into existence, both nationally and internationally. It is important that the rules of arbitral institutions should be altered to reflect these changes and not rest in some comfortable time wrap. The ICA rules are in accordance with the IACA, 1996. For instance, the appointment of sole arbitrator or three arbitrators in the arbitral tribunal is in harmony with section 10(1) of the IACA, 1996.

3. Qualified Staff - One of the main objects of an arbitral institution is to assist arbitrators and the parties in the conduct of arbitration. This assistance may extend not only to explaining the rules, making sure that the time limits are observed, collecting fees, arranging visas and reserving accommodations, but also to advising on appropriate procedures by reference to past experience. It is a task that requires a combination of qualities, tact and diplomacy as well as legal knowledge and experience.

It is an area in which ICC sets the standard, with each arbitration being under the supervision of a designated "Counsel", drawn from the ICC' staff of experienced and multi-lingual lawyers. Though, the ICA does not has such a designated counsel to supervise arbitration, it does boats a panel of around 1500 arbitrators with an extensive array of professional qualifications and expertise (legal and non- legal), guaranteeing a tribunal of the highest aptitude and proficiency. The ICA has access to the most eminent and experienced arbitrators and with the widest range of expertise from India, U.K., Singapore, France, USA, Malaysia, Germany and Belgium.
4. Reasonable Charges - The process of Arbitration is deemed efficacious if along with being expeditious and just, it is cost effective as well. Some arbitral institutions including the International Chamber of Commerce and the Indian Council of Arbitration assess their own administrative fees and expenses, and the fees payable to the arbitrator, by reference to a sliding scale which is based on the amounts in dispute. This has the advantage of certainty, in that the parties can find out at a reasonably early stage what the total cost of arbitration is likely to be.Other institutions, such as the LCIA, assess their administrative costs and expenses, and the fees of the arbitrator, by reference to the time spent on the case.

\section{CONCLUSION}

The Arbitration Conciliation Act, 2015 has made an attempt to come to rescue in this regard by fixing fees and timeline for arbitration but the thorn in the flower is that courts are again to intervene to investigate as to who is to be blamed for the delay in meeting the timeline. Further, the High Courts have been provided the power to make rules for fees and the manner of payment which again would lead to lack of uniformity as each High Court of different states across India would have their own rules. Therefore, one needs to promote Institutional Arbitration in India.

It is universally acknowledged that, the quality of arbitration proceeding depends on the quality and skill of the arbitrators chosen and the Courts may not have the expertise in appointment of arbitrators who would be expert qua the subject matter in dispute. Moreover, in International Commercial Arbitrations, a national court judge understandably will have limited experience, expertise and resources for selecting suitable international arbitrators; particularly if practitioners form other countries must be selected. While having an arbitral institution making an appointment would be more beneficial as then they would be specifically organized to perform the function of selecting international arbitrators because of their day-to-day involvement in international arbitration and access to a pool of highly qualified arbitrators.

Also, Institutional Arbitration should be promoted where arbitration is carried out on a day to day basis say for 
instance $10 \mathrm{am}-4 \mathrm{pm}$ so that there is no backlog of cases or delay in concluding the arbitration proceedings. Fees issue would also be taken care of by Institutional Arbitration as such Institutions have a fix fee schedule which will negate space for ambiguity

Further, steps can be taken to make the order passed by the Arbitrator under Institutional Arbitration open to appeal or review only by a President/Registrar(Head) of the Institution so as to negate parties taking the court route and the decision of the abovementioned authority can be made final and binding upon the parties and also the parties shall be taken to have waived any right to appeal or review in respect of any decision of the abovementioned authority to any state court or other judicial authority. Besides, Court intervention in arbitration proceeding could be allowed only when arbitration agreement specifically provides for it.

We should make Institutional Arbitration an attractive hub for foreign parties and investors, certain things are to be kept in mind like a forum is attractive as a seat only if it has a judiciary that is supportive of arbitration. Further, the Institutions conducting Arbitrations in India should be provided ample resources and opportunities to participate in important international arbitration conferences and to host one to two major international arbitration conferences at least in a year so that it would invite worldwide participation/attention and exposure that can enhance the international image of Institutional Arbitrations in India and attract foreign parties to arbitrate in India.

Thus, Institutional Arbitrations should be given a green flag with patient expectations about its results rather than taking any hasty decisions because one thing is trustworthy that if countries like Singapore and Hong Kong can become Arbitration hubs on the strength of Institutional Arbitrations, so can India. India is on the track of establishing confidence in its legal system which is the fundamental condition for any country to become an international arbitration venue.

\section{REFERENCES}

1. ALSAIAT, ASAM SAUD S. "The Legal Frameworks That Govern Electronic Arbitration Processes And Its Role In Resolving International Trading Contracts Disputes." International Journal of Political Science, Law and International Relations (IJPSLIR) 8.2 (2018) $1-8$

2. KUMAR, ARUN. "DEMOCRATIC TRANSITION AND INSTITUTIONALIZATION OF PARTY SYSTEM IN ESTONIA, 1991-2001." IMPACT: International Journal of Research in Humanities, Arts and Literature (IMPACT: IJRHAL) 5.6 (2017) 21-36

3. Tamoria, Ferdinand V., Ma Nympha B. Joaquin, and Milagros D. Ibe. "STATE INSTITUTIONAL CHARACTERISTICS AND TEACHER QUALITIES: EFFECTS ON CURRICULUM ADAPTATION IN MATHEMATICS TEACHER EDUCATION." International Journal of Humanities and Social Sciences (IJHSS) 7.4 (2018) 147-160

4. Dagbusan, Bobby T. "CHALLENGES AND PROSPECTS OF LEADERSHIP DEVELOPMENT OF LGUS IN TAWI-TAWI: TOWARDS A SUSTAINABLE SOCIOECONOMIC AND POLITICAL AGENDA." IMPACT: International Journal of Research in Humanities, Arts and Literature (IMPACT: IJRHAL) 7.4 (2019) 527-536

5. SINGH, ALOK, and SANDEEP MONDAL. "SYSTEMATIC REVIEW AND RESEARCH AGENDA ON BLOOD SUPPLY CHAIN." International Journal of Business Management \& Research (IJBMR) 8.6 (2018) 9-18

6. Majumder, Mithun. "POLITICAL PARTICIPATION OF WOMEN IN INDIA: AN ANALYSIS OF WEST BENGAL AFTER REGIME-CHANGE." IMPACT: International Journal of Research in Humanities, Arts and Literature (IMPACT: IJRHAL) 8.2 (2020) 5762 